\title{
Corridor as A Transition at Tourism Area in Yogyakarta
}

\author{
Irfan Hertanto ${ }^{1}$, Endang Titi Sunarti $D^{1}$, Murni Rachmawati ${ }^{1}$
}

\begin{abstract}
Yogyakarta is always flooded by tourists both domestic and foreign. Malioboro street corridor, from Tugu Station to Keraton Yogyakarta, is one of the most visited tourism area in Yogyakarta. However, Ahmad Dahlan's corridor as one of the important access that link the tourism area reduces its identity by the declining quality of its outdoor space. The analysis techniques are spatial behavior analysis, character appraisal and walkthrough analysis. The study found that declining quality of the outdoor space, such as lack of identity and sustainable street furniture that supports the activities of visitors in tourism areas. In this case, the linkage design, as a transition must be able to show the identity of the corridor to connect the surrounding area visually and spatially.
\end{abstract}

\section{Keywords-Linkage, Corridor, Yogyakarta.}

\section{INTRODUCTION}

Yogyakarta is the second largest tourism destination in Indonesia. It always flooded by tourists both domestic and foreign. Malioboro street corridor, from Tugu Station to Keraton Yogyakarta, is one of the most visited tourism area in Yogyakarta. Ahmad Dahlan corridor is one of the important access that link the tourism area [1]. It linked the tourism area and its parking area on the west side of the corridor (figure 1). The corridor located right in the corner of Yogyakarta's zero-point axis together with 3 other major corridors.

The declining quality of Ahmad Dahlan's outdoor space badly reduces its identity, and it weakened its linkage to the surrounding areas, even its own parking zone was not "connected" to the main tourism area. Ngabean parking zone as an official parking zone for the tourism areas itself actually existed there for a long time. The main problem for this tourism areas is that there is no transitional space for visitors who come from outside this area. Visitors who park their cars or take a tourist bus to Ngabean parking zone did not greeted by a clear direction to the tourism areas. For this reason, it's important to identify the quality linkage of Ahmad Dahlan corridor.

${ }^{1}$ Irfan Hertanto, Endang Titi Sunarti D, Murni Rachmawati are with Department of Architecture, Faculty of Architecture, Design, and Planning, Institut Teknologi Sepuluh Nopember (ITS), Kampus ITS Sukolilo, Surabaya 60111, Indonesia. E-mail: irfan15@mhs.arch.its.ac.id; endar@arch.its.ac.id; murnirach@arch.its.ac.id.

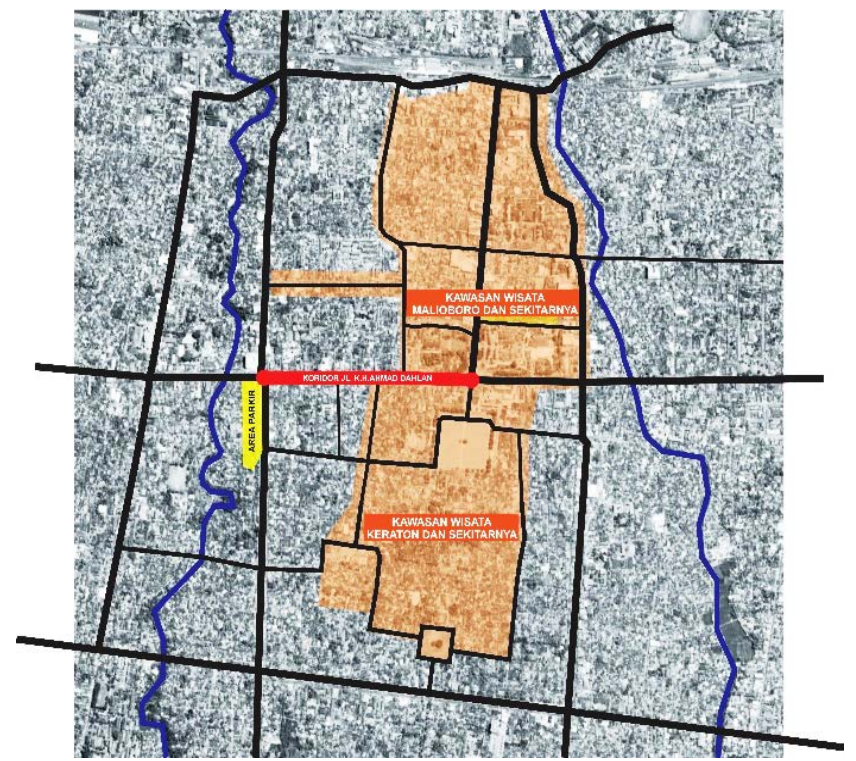

Figure 1. Ahmad Dahlan corridor (red) as a transition between tourism areas (orange) and its supporting area (yellow).

\section{LITERATURE REVIEW}

The image of the city in the strategic area determines Ahmad Dahlan road as a corridor that implies the image of culture and passive tourism activities as mentioned in Rencana Tata Ruang Wilayah (RTRW) Kota Yogyakarta 2010-2029 [1].

The walkthrough analysis technique is used to analyze urban quality and the problems of a design done by walking along the road and recording its observations using graphical methods (photographs or drawings). Spatial Behavior analysis is an observation by following people activities (static and dynamic) and recording them in maps and diagrams. Used to understand how the physical aspects of an environment affect social activity and behavior by recording the use of urban space by the community. The results of this analysis in the form of activity maps or behavior maps and diagrams along with explanations. Character Appraisal analysis is an analysis technique used to identify areas that have strong character and high authentication [2].

The city as a physical environment has various aspects that can lift, develop and characterize the city itself, such as historical value and other factual aspects that produce identities for the city. In this study, paths are the most important elements to find linkage with walkthrough analysis. Paths are circulation routes that people typically use to make movements in general, such as roads, main 
aisles, transit roads, and others. Paths have a better identity if they have large basic goals (eg stations, monuments, squares, etc.), and there are strong visions (eg facades, trees, etc.), or clear bends [3].

According to Kevin Lynch in Good City Form (1979), identity is the extent to wich a person can recognize or recall a place as being distinct from other places as having vivid, or unique, or at least a particular, character of its own [4].

\section{METHOD}

The data collection method used is to conduct interview and field survey, to see the quality of the linkage of the studied corridor. The study area is a 930 meters outdoor space in Ahmad Dahlan corridor. The data analysis techniques are spatial behavior analysis, walkthrough analysis and character appraisal.

The walkthrough analysis used to identify the linkage of the studied corridor, the technique is carried out to obtain a description of design issues on the Ahmad Dahlan corridor and help to establish the extent of the problem to determine the next step in solving the problem in the corridor.

The spatial behavior analysis used to find the outdoor space of Ahmad Dahlan corridor that mostly and highly used by pedestrians. The observation time divided into two section, first observation is $12.45 \mathrm{pm}$ at noon and second observation is $16.30 \mathrm{pm}$ at afternoon, not only weekdays but also on holidays. The selection of these hours is based on community activities and outdoor space users.

And the character appraisal analysis used to identify linkage and specific identity of the Ahmad Dahlan corridor. One of the process of this analysis is to identify buildings character and its outdoor space.

\section{RESUlts AND Discussion}

\section{A. Walkthrough Analysis}

The identification and analysis of Walkthrough analysis found that visually and spatially outdoor space of Ahmad Dahlan corridor are still not well ordered. The study also found the grouping of building facades with similar style. Colonial architectural style is found in many buildings on the east side of the Ahmad Dahlan corridor, but also spread along the corridor although the number is not much.

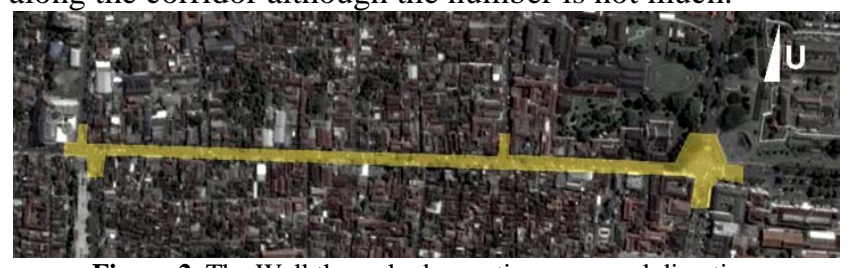

Figure 2. The Walkthrough observation areas and direction.

The walkthrough observation started from Ngabean parking area on the west to the Point Zero of Yogyakarta city on the east. The observation done by taking pictures and collecting data while walking to the east, simulating tourists coming from Ngabean parking area to the tourism area (figure 2).
The western intersection that connected to the Ngabean parking area is the entrance for Ahmad Dahlan corridor and the surrounding tourist area, but visually there is no visible identity to the existence of the corridor. Tourist were left "surprised" by the large tourism area at the other end of the corridor, without any reception area or opening area before. The sidewalk area meets the minimum standards and there is no bike paths yet. The convenience of pedestrians is disrupted by the presence of tent stalls (PKL) at some pavement points, leaving only about $20 \%$ of pedestrian street space. This can be worsened when there is a vehicle (motorcycle) parked on the sidewalk during high season. Zebra Cross are exist around the zero point of Yogyakarta, many people use it though no crossing lights and the paint marker has faded.

TABLE 1.

WALKTHROUGH ANALYSIS RESULTS Walkthrough Analysis Results

Potential.

- The entire corridor has the potential use of outer space is good enough with the surrounding tourist areas.

- Potential to be an identity for the area around it, because it is located in the western end of the tourist area and identical as the entrance for the surrounding tourist area.

Problems.

- Inadequate corridor conditions and lack of existing facilities lead to poor quality of detailed corridors, both visually and spatially, such as street furniture, the existence of pavement materials, the space character formed by outer space of buildings, as well as the access and connectivity of pedestrian paths on the sidewalk.

\section{B. Spatial Behavior}

The observation devided into two section times. $12.45 \mathrm{pm}$ is chosen because the average is a break or lunch time where people usually go or exercise in the outdoors for rest or foraging. On holidays at $12.45 \mathrm{pm}$ is also an average time in which many tourists are in the outer space of this area. The second observation time is at $16.30 \mathrm{pm}$, it is chosen based on the average hours (of work, school for children, or retail activities such as workshops, banks, and others) begin to gradually close or go home and see more activities in the outdoor space of the corridor. In addition, the tourists who are in the tourism area mostly choose time around $16.30 \mathrm{pm}$ to "get ready" to go back to their hotels, vehicles, or homes before "maghrib", which for most people of Indonesia it is the time to go home.

The respondents divided into two range of age. Age 35 and under is categorized as a junior user, and age 36 and above is categorized as a senior user. The sample is taken by observing and recording the human activities that exist within the corridor, with a maximum span of 30 minutes on every 1st observation on the outer space of the corridor as a whole, then the average existing activity is inserted into the keymap image as colored dots (red and green). 
TABLE 2.

SPATIAL BEHAVIOR ANALYSIS (WEEKENDS)

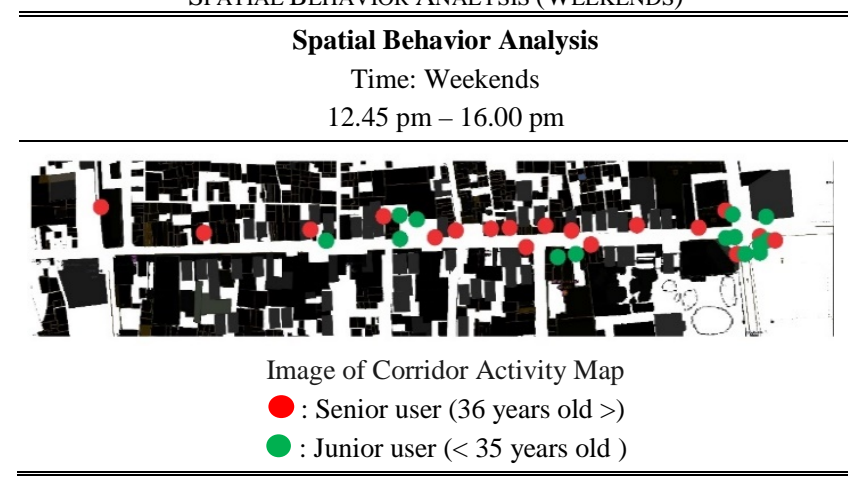

From the diagram (Table 2) shows the spread of the use of space outside the corridor Ahmad Dahlan street not only a lot located in the eastern area, which is at the "Titik Nol kota Yogyakarta", but also spread to the middle area of the corridor.

The junior user type is larger in terms of the percentage of presence around "Titik Nol" area. Most of them are domestic tourists who deliberately came to Yogyakarta for a vacation and see the tourist area.

Some other activities occupy the middle area of this corridor, precisely located around the area "Ragam Kriya", a place that sells various types of batik, handicrafts, and culinary typical city of Yogyakarta, so that many domestic tourists and foreign tourists come to this place.

Along the outer space of the corridor there are many seasonal traders, such as batik traders, souvenir merchants, food and beverage merchants only open during holidays or long holidays. It lies along the corridor from the east to the middle area.

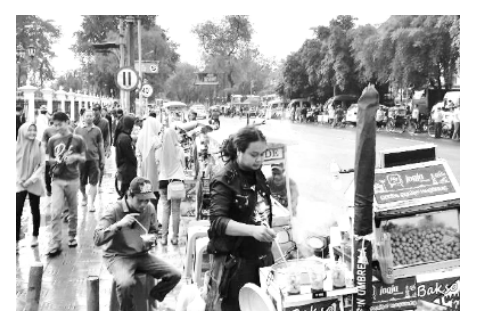

Figure 3. Street vendors.

Some street vendors are seen in the Titik Nol kota Yogyakarta (Yogyakarta point zero) area. Almost all of them are merchants with wheelbarrows that are easily to move.

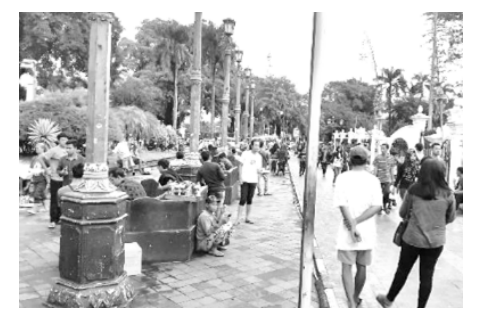

Figure 4. Open spaces used by tourists.

The open space in Titik Nol kota Yogyakarta (Yogyakarta point zero) area becomes the most used area on a holiday.
TABLE 3. SPATIAL BEHAVIOR ANALYSIS (WEEKDAYS)

\section{Spatial Behavior Analysis}

Time : Weekdays

$12.45 \mathrm{pm}-16.00 \mathrm{pm}$

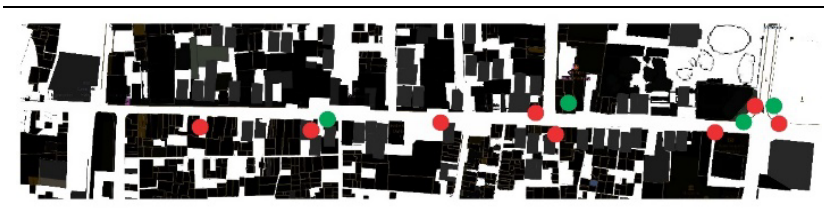

Image of Corridor Activity Map

: Senior user (36 years old $>$ )

: Junior user $(<35$ years old $)$

From the diagram above shows the spread of the use of outdoor space in the Ahmad Dahlan corridor are mostly in the eastern area, which is at the intersection of point zero of Yogyakarta city. The types of senior and junior users are equally average in terms of percentage of attendance. Most of them are domestic tourists who want to spend free time in the open area while taking pictures.

Another set of visible activities is in the middle area of this corridor, precisely located around the hospital PKU Muhammadiyah. The types of activities here are mostly related to hospitals, such as motorcycle parking crowds in front of hospitals, and the activities of food stalls lining the sidewalks around which are mostly filled by patient watchers. In addition, this area is located in a node, the intersection of Bhayangkara road so that the amount of traffic in this area is quite solid.

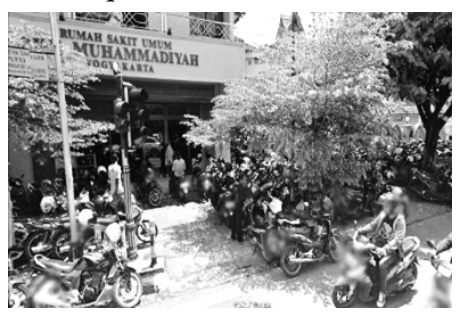

Figure 5. Motor bike parking.

Motorbike parking in the front area of PKU Muhammadiyah Hospital which is full during the daytime. Most vehicles are parked under existing trees to avoid the heat of the sun.

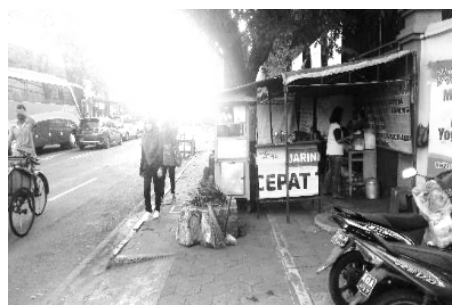

Figure 6. Food stalls on the sidewalk.

Food stalls on sidewalks in the area around PKU Muhammadiyah hospital.

To identify the most used outdoor space, researcher merged 'spatial behavior map' into a 'building types map', then the activity and the buildings nearby can be analyzed. 


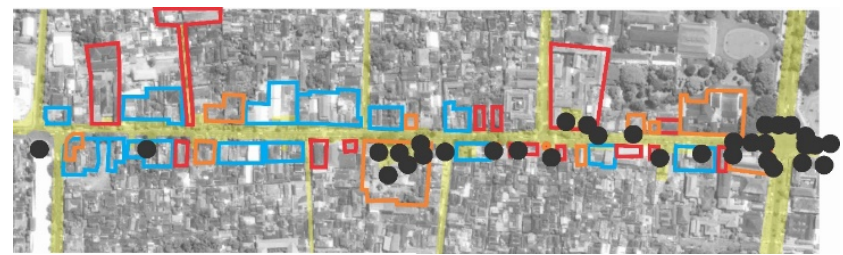

Figure 7. Corridor activity map and building types

The Spatial Behavior identification and analysis found the existence of activity points from the surrounding community and the corridor users directly affected by the increasing function of Ahmad Dahlan corridor. Weekends and holidays is the time when there is the most activity in the outdoor space of Ahmad Dahlan corridor, mostly are in the area Ragam Kriya (in the center of the corridor) and in the Point Zero of Yogyakarta city.

TABLE 4.

SPATIAL BEHAVIOR ANALYSIS RESULTS

Spatial Behavior Analysis Results

Potential.

- With various types of activities in the Ahmad Dahlan corridor, it shows its potential of having dedicated outdoor spaces which can be used as a centralized area of activity such as a relaxation area, selling souvenirs area, park or open public space.

Problems.

- With so many different types of activities on the outdoor space of the Ahmad Dahlan corridor that have been described earlier, the apparent problems are the lack of arrangement of the outdoor space and its activities, causing the corridor to be not organized, such as food stalls or street vendors that use up pedestrian paths or even the road.

\section{Character Appraisal}

The Character Appraisal analysis shows the conditions of elements inside the studied corridor.

TABLE 5.

THE OUTDOOR ELEMENTS

Outdoor Elements Condition

The corridors can be accessed from end to end by walking, but sometimes in several places, pedestrian access is used by hawkers activity and motorcycle parking.

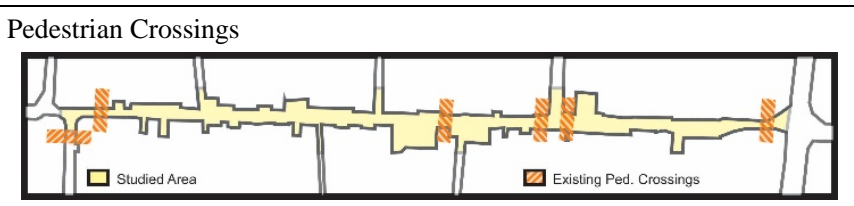

The distance between crossings with each other on road corridors Ahmad Dahlan is still more than 200 meters, has not met the standard between 120 meters to 180 meters.

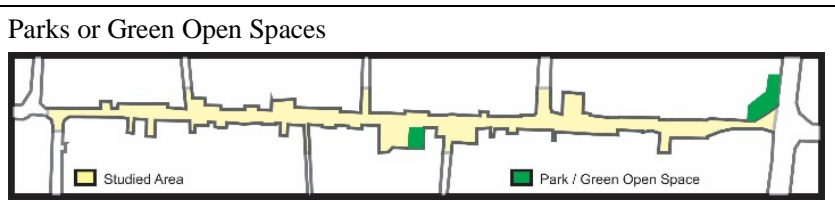

Not many green open spaces exist in this corridor, its presence does not show any identity from the surrounding area.

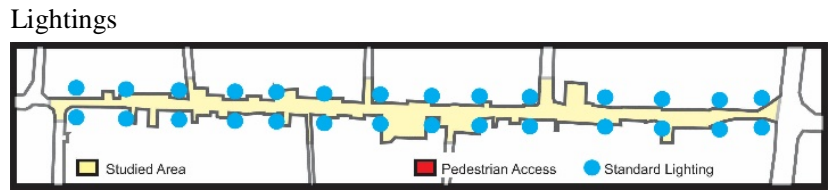

Even this corridor is located in the center of Yogyakarta's tourism area, the lightings in this entire corridor are street standard lightings with no ornaments on it. Different from Malioboro street that have pedestrian oriented lightings with traditional ornamental design.

By combining the result of spatial behavior analysis and the Character Appraisal analysis, resesarcher found that outdoor space of Ahmad Dahlan corridor has 3 groups of zones in which there are types of buildings that can broadly indicate the identity of each zone, but the arrangement of its outdoor space elements are still not in accordance with the condition of the identity of the region.

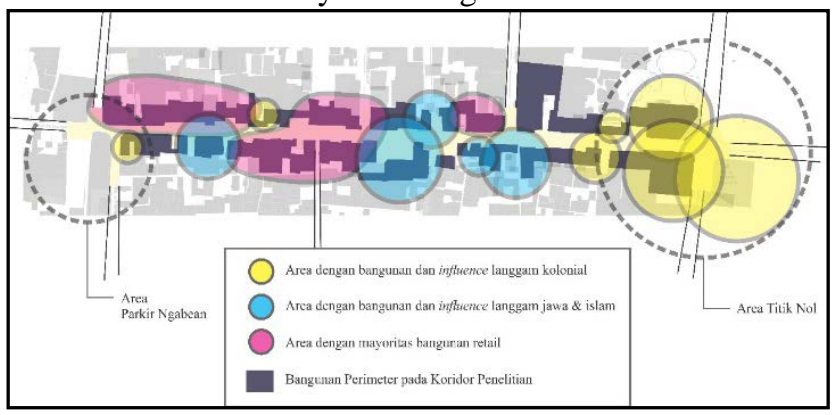

Figure 8. The result of character appraisal analysis.

On the far east (yellow areas) there are areas with influences of mostly Colonial buildings such as BNI46 Bank, Yogyakarta Post Office, and Gedung Agung building. On the center area (blue areas) there are areas with Kauman and traditional influences buildings. On the west area (purple areas) there are areas with mostly retail buildings on it. The outdoor space does not seems to linking the entire corridor. Arrangement of the elements of outdoor space are required for all three zones according to their each zone's identity.

\section{CONCLUSION}

Condition of the Ahmad Dahlan's corridor identity itself did not appear at this time. It takes a restructuring and enhancing the identity to be able to meet the imagery needs in the existing corridor. Existing corridors are said to be plain or do not reveal their identity as receiving corridors. Users did not given any information about the tourism area at the end of its corridor. Besides, the identity identification shows that there are some old buildings with colonial and traditional influence but did not highlighted in this corridor.

The condition of connectedness or linkage of the outdoor space in this corridor is still very irregular. Many pedestrian access are cut off by other types of activities. Visually connectedness is also not visible because of the absence of outdoor space elements that interconnecting the corridor's identity.

Spatial restructuring on Ahmad Dahlan corridor is important, considering its potential as a linkage for the 
whole tourism areas and its parking zone can bring a huge economic improvement into surrounding areas.

As a transition area, this corridor must be able to clarify its linkage and its identity [4], so it will connect the surrounding area both visually and spatially.

\section{REFERENCES}

[1] PEMPROV NO. 2 TAHUN 2010, Rencana Tata Ruang Wilayah
Provinsi Daerah Istimewa Yogyakarta Tahun 2009-2029. .

[2] Ministry for the Environment, Urban Design Toolkit, 3rd ed. Wellington New Zealand: Ministry for the Environment of New Zealand, 2009.

[3] K. Lynch, The Image of the City. Cambridge, Massachusetts: MIT Press, 1960.

[4] K. Lynch, Good City Form. Cambridge, Massachusetts: MIT Press, 1984. 